\title{
Prevalence of Tritrichomonas foetus and Campylobacter fetus subsp. venerealis among bulls slaughtered in the state of Minas Gerais, Brazil
}

\section{Prevalência de Tritrichomonas foetus, Campylobacter fetus subsp. venerealis e de Campylobacter fetus subsp. fetus em touros abatidos no Estado de Minas Gerais, Brasil}

\author{
Michele Placedino Andrade Botelho'; Christian Hirsch²; Andrey Pereira Lage ${ }^{3}$; \\ Christiane Maria Barcellos Magalhães da Rocha²; Elaine Maria Seles Dorneles²; \\ Patrícia Gomes Cardoso ${ }^{4}$; Geraldo Márcio da Costa ${ }^{2 *}$
}

\begin{abstract}
Bovine genital campylobacteriosis (BGC) and bovine genital trichomonosis (BGT) are globally widespread, predominantly sexually transmitted diseases that mainly affect herds in which natural mating takes place. Bulls serve as good epidemiological indicators for studying the causative agents of these diseases in cattle herds. The objective of the present work was to determine the prevalence of BGC and BGT among bulls sent to slaughterhouses in southern Minas Gerais, Brazil. Samples of preputial smegma from 200 sexually mature, non-castrated bulls of several ancestries were collected in 2013 from four regional slaughterhouses. The polymerase chain reaction (PCR) was employed to detect Tritrichomonas foetus, Campylobacter fetus subsp. fetus, and C. fetus subsp. venerealis. Isolation also was used aiming to diagnosis of BGT. All smegma samples were negative in culture for T. foetus. Molecular tests revealed 8\% (16/200) of animals to be positive for T. foetus, $17.5 \%$ (35/200) for Campylobacter. fetus subsp. fetus, and 13.5\% (27/200) for C. fetus subsp. venerealis. The results of the present study indicate that $T$. foetus, $C$. fetus subsp. venerealis, and C. fetus subsp. fetus are present among bulls slaughtered in southern Minas Gerais, and that BGC and BGT occur in this region. These diseases therefore need to be considered during differential diagnosis of reproductive diseases affecting cattle herds in which natural mating is employed.
\end{abstract}

Key words: Campylobacteriosis. Bovine diseases. Diagnosis. PCR. Reproductive diseases. Trichomonosis.

\section{Resumo}

A Campilobacteriose Genital Bovina (CGB) e a Tricomonose Genital Bovina (TGB) são doenças de transmissão predominantemente venérea, de ampla disseminação mundial, acometendo principalmente

1 Discente, Curso de Mestrado do Programa de Pós-Graduação em Ciências Veterinárias, Departamento de Medicina Veterinária, Universidade Federal de Lavras, UFLA, Lavras, MG, Brasil. E-mail: micheleplacedino@yahoo.com.br

2 Profs., Departamento de Medicina Veterinária, UFLA, Lavras, MG, Brasil. E-mail: chhirsch@dmv.ufla.br; rochac@dmv.ufla.br; eleine.dorneles@dmv.ufla.br; marciocostavet@gmail.com

3 Prof., Departamento de Medicina Veterinária, Escola de Veterinária, Universidade Federal de Minas Gerais, EV/UFMG, Belo Horizonte, MG, Brasil. E-mail: alage@vet.ufmg.br

4 Prof $^{\text {a }}$, Departamento de Biologia, UFLA, Lavras, MG, Brasil. E-mail: patricia@dbi.ufla.br

* Author for correspondence 
rebanhos submetidos à monta natural. Touros constituem bons indicadores epidemiológicos para a pesquisa destes agentes nos rebanhos. O objetivo deste estudo foi determinar a prevalência da CGB e da TGB em touros encaminhados a abatedouros da região sul de Minas Gerais, Brasil. Amostras de esmegma prepucial de 200 touros (machos não castrados em idade compatível com a monta) de diversas genealogias foram coletadas em quatro abatedouros da região, no ano de 2013. A reação em cadeia da polimerase (PCR) foi utilizada para detecção dos patógenos Tritrichomonas foetus, Campylobacter fetus subsp. fetus e Campylobacter fetus subsp. venerealis. O isolamento também foi utilizado para o diagnóstico da TGB. Todas as amostras analisadas apresentaram resultado negativo na cultura para isolamento de $T$. foetus. Por meio dos testes moleculares, verificaram-se prevalências de $8 \%(16 / 200)$ de animais positivos para T. foetus; 17,5\% (35/200) para C. fetus subsp. fetus e de 13,5\% (27/200) para C. fetus subsp. venerealis. Os dados do presente estudo apontaram a presença de T. foetus, C. fetus subsp. venerealis e C. fetus subsp. fetus em touros abatidos na região sul de Minas Gerais, evidenciando a ocorrência da TGB e da CGB nesta região e a necessidade de inclusão destas enfermidades no diagnóstico diferencial das doenças da reprodução em rebanhos bovinos submetidos à monta natural.

Palavras-chave: Campilobacteriose. Diagnóstico. Doenças de bovinos. Doenças reprodutivas. Tricomonose. PCR.

\section{Introduction}

Brazil has the world's largest population of commercial cattle, estimated at 212.8 million animals, and cattle farming is of great socioeconomic relevance in this country, enjoying a privileged position in Brazilian agribusiness and contributing to the settling of rural areas. Among the states of the Southeast Region, Minas Gerais (MG) stands out as having largest cattle population, representing $11 \%$ of the total in Brazil (IBGE, 2015), and being the leading milk producer, having produced approximately 6.5 billion liters in 2016 (IBGE, 2017).

Sanitary problems are a limiting factor in the livestock industry, increasing production costs and reducing the competitiveness of the goods produced. Of these problems, reproductive diseases have an important effect owing to their insidious and disseminated nature, and eventually compromise the reproductive performance of the affected animals (FASSIO et al., 2006). The protozoan Tritrichomonas foetus and the bacterium Campylobacter fetus subsp. venerealis are among the main causative agents of reproductive diseases in cattle submitted to mate naturally. These microorganisms cause bovine genital trichomonosis (BGT) and bovine genital campylobacteriosis (BGC), respectively. The bacterium Campylobacter fetus subsp. fetus is the causative agent of sporadic abortus in cows (ALVES et al., 2011). Despite the fact that they are globally widespread, studies concerning these diseases remain scarce in Brazil, where management practices predominantly based on natural mating certainly favor their occurrence (ALVES et al., 2011; MICHI et al., 2016).

$\mathrm{BGC}$ and $\mathrm{BGT}$ are responsible for considerable economic losses in the livestock industry, mainly due to the temporary infertility of infected females and resulting prolongation of the interval between pregnancies (BONDURANT, 2005; ALVES et al., 2011), indirect expenses due to professionals' fees, and costs related to the diagnosis, treatment, and disposal of infected animals (PELLEGRIN, 2002). Furthermore, BGC and BGT feature in the list of notifiable diseases maintained by the World Organization for Animal Health (OIE), which include transmissible diseases of socioeconomic importance and public health concern and therefore relevant to the international trade of animals and animal products (OIE, 2012).

The economic impact of these diseases with respect to Brazilian herds has been little investigated, and the studies that are available are scarce and obsolete (STYNEN et al., 2003; ROCHA et al., 2009; LEAL et al., 2012). This probably results from the lack of effective diagnostic routine methods, 
along with problems associated with shipping and laboratory analyses of clinical samples, and the small number of laboratories with the technical capacity to diagnose these diseases (PELLEGRIN; LEITE, 2003).

The majority of studies concerning BGC and BGT carried out in Brazil have used traditional diagnostic methods, such as isolation (LEITE et al., 1997; ROCHA et al., 2009), mucus agglutination (CASTRO et al., 1971), and direct immunofluorescence (STYNEN et al., 2003; LEAL et al., 2012). However, these tests have low sensitivity and specificity (MCMILLEN et al., 2006), constituting a serious obstacle to understanding the real importance of these diseases in Brazilian herds.

Despite advances in molecular biology, the use of molecular tests in the diagnosis of BGC and BGT in Brazil remains rather rare. Indeed, no previous studies using such tests to detect BGT are to be found in the Brazilian researches. Concerning BGC, only a single report exists in which these diagnostic tests were applied to Brazilian herds, and only a small number of such studies have been performed in other countries (MADOROBA et al., 2011; HAMALI et al., 2011). In general, molecular tests offer the advantages of high sensitivity and specificity without the need to preserve the feasibility of pathogen in question. In the case of BGC and BGT, these benefits mean that such tests likely generate more reliable estimates of pathogen prevalence than conventional diagnostic methods, mainly the isolation, due to the low viability of the causative agents, especially when transport and enrichment media (TEM) are not utilized (BONDURANT, 2005).

Considering the importance of BGC and BGT in cattle submitted to natural mating and the scarcity of recent data concerning these diseases among Brazilian herds, the objective of the present work was to determine their prevalence among bulls sent to slaughterhouses in southern Minas Gerais during 2013.

\section{Material and Methods}

All procedures carried out in this study complied with regulatory standards for biosafety and ethics, having been approved by the Ethics Committee on Animal Experimentation (CEUA) of the Federal University of Lavras, process nr. 048/13.

The present study was performed in the southeast region of the state of Minas Gerais, Brazil, using samples of preputial smegma collected from bulls slaughtered in four slaughterhouses in three municipalities: Perdões (1), Boa Esperança (1), and Campo Belo (2). In keeping with the Guidelines for Animal Transport (GTA), the bulls were mainly originated from herds located in municipalities of southern Minas Gerais.

Non-castrated bulls in the slaughter line were selected for the study, with animals raised under confinement or less than 2 years old being excluded in order to increase the chances of sampling sexually active bulls. Convenience sampling was used to select 200 bulls (non-castrated males of mating age) of various genealogies from slaughterhouses in southern Minas Gerais during December 2013. Given the capacity of the slaughterhouses and availability of animals meeting these criteria, 200 samples of preputial smegma were collected in total, consisting of 116, 20, and 64 samples from the slaughterhouses in Campo Belo, Perdões, and Boa Esperança, respectively.

Samples were collected immediately after the animals had been stunned and slaughtered. The penis, including the prepuce, was sectioned using a knife and cleaned with single-use paper towels when excessive dirt was present. The penis was exposed on a tray using a rat-tooth forceps, and the entire penis and preputial regions were scraped with a spatula to retrieve the smegma. All tools, including trays, forceps, spatulas, and gloves, were changed after each sample to avoid cross-contamination. The smegma samples were stored in properly labeled sterile flasks containing $5 \mathrm{~mL}$ sterile saline solution, which were then placed in thermal boxes 
at room temperature and promptly transported to the laboratory.

The methodology described by Pellegrin and Leite (2003) was used to isolate T. foetus. For this propose, a $200-\mu \mathrm{L}$ aliquot of each freshly collected smegma sample was spread on Lactopep ${ }^{\mathrm{T}}$ medium within $12 \mathrm{~h}$ after collection. The cultures were then placed in an incubator at $37^{\circ} \mathrm{C}$ and analyzed by darkfield microscopy at $100 \times$ and $400 \times$ magnification every day between the $1^{\text {st }}$ and $7^{\text {th }}$ days of incubation. The presence of at least one protozoan exhibiting the morphology and motility typical of $T$. foetus was sufficient to categorize the sample as positive for this organism. Samples of Trichomonas vaginalis strain FMV-1 and T. foetus strain $\mathrm{K}$ were used as references to control the culture medium quality. After spreading a portion of each sample on Lactopep medium, the remaining smegma material was frozen at $-20{ }^{\circ} \mathrm{C}$ for later use in molecular tests.

Simplex and multiplex PCR for the detection of the target disease agents (T. foetus, C. fetus subsp. fetus, and C. fetus subsp. venerealis) were carried out using DNA extracted from preputial smegma as a template. Prior to DNA extraction, the samples were treated in a concentrator (model 5301; Eppendorf, Hamburg, Germany) in order to increase the sensitivity of the molecular tests. The samples were concentrated by reducing their volume (in $0.85 \%$ saline solution at $\mathrm{pH} 7.2$ ) from $1.5 \mathrm{~mL}$ to $150 \mu \mathrm{L}$.

DNA was extracted using a commercial kit (DNeasy ${ }^{\circledR}$ Blood \& Tissue Kit; QIAGEN, Venlo, The Netherlands) following the manufacturer's instructions. The DNA samples were subsequently stored at $-20^{\circ} \mathrm{C}$ until their use in PCR assays, which were performed in a PT100 thermocycler (Applied Biosystems, Carlsbad, USA).

The ITS1 region of rDNA was amplified for the detection of $T$. foetus using the primers described by Felleisen et al. (1998), which generate a 347-bp amplicon (Table 1). Each PCR comprised a solution

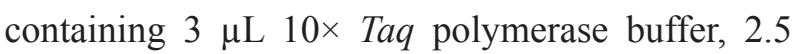
$\mu \mathrm{L} 50 \mathrm{mM} \mathrm{MgCl}, 1.0 \mathrm{mM}$ dNTPs, 2 U Taq DNA polymerase, $10 \mu \mathrm{M}$ each primer, $10 \mu \mathrm{L}$ template DNA, and ultrapure water up to a final volume of $30 \mu \mathrm{L}$. Cycling conditions were as follows: $95^{\circ} \mathrm{C}$ for $5 \mathrm{~min} ; 40$ cycles of $95^{\circ} \mathrm{C}$ for $30 \mathrm{~s}, 66^{\circ} \mathrm{C}$ for $30 \mathrm{~s}$, and $72{ }^{\circ} \mathrm{C}$ for $90 \mathrm{~s}$; and a final extension at $72{ }^{\circ} \mathrm{C}$ for 15 min. DNA samples from Trichomonas vaginalis strain FMV-1 and T. foetus strain $\mathrm{K}$, both isolated in the context of a clinical case, were used as positive controls in the molecular tests.

Table 1. Primers used in PCR for detection of Tritrichomonas foetus and in the multiplex PCR for detection of Campylobacter fetus subsp. fetus and C. fetus subsp. venerealis in samples of preputial smegma from bulls.

\begin{tabular}{cccc}
\hline Microorganisms & Sequence of primers & PCR products & References \\
\hline Tritrichomonas foetus & $\begin{array}{r}\text { TFR3-5'CGGGTCTTCCTATATGAGACAGAACC-3' } \\
\text { TFR4-5'CCTGCCGTTGGATCAGTTTCGTTAA-3' }\end{array}$ & $347 \mathrm{pb}$ & $\begin{array}{c}\text { Felleisen et } \\
\text { al. (1998) }\end{array}$ \\
\hline $\begin{array}{c}\text { Campylobacter fetus } \\
\text { subsp. fetus }\end{array}$ & $\begin{array}{r}\text { MG3F-5'GGTAGCCGCAGCTGCTAAGAT-3' } \\
\text { MG4R-5'TAGCTACAATAACGACAACT-3' }\end{array}$ & $750 \mathrm{pb}$ & $\begin{array}{c}\text { Hum et al. } \\
\text { (1997) }\end{array}$ \\
$\begin{array}{c}\text { Campylobacter fetus } \\
\text { subsp. venerealis }\end{array}$ & $\begin{array}{r}\text { VenSF-5'CTTAGCAGTTTGCGATATTGCCATT-3' } \\
\text { VenSR-5'GCTTTTGAGATAACAATAAGAGCTT-3' }\end{array}$ & $142 \mathrm{pb}$ & \\
\hline
\end{tabular}

Multiplex PCR was carried out to identify $C$. fetus subsp. fetus and C. fetus subsp. venerealis using the primers described by Hum et al. (1997) (Table 1). Each reaction comprised a solution containing $3 \mu \mathrm{L} 10 \times \mathrm{Taq}$ polymerase buffer, $2.5 \mu \mathrm{L}$
$50 \mathrm{mM} \mathrm{MgCl}_{2}, 1.0 \mathrm{mM}$ dNTPs, 1.5 U Taq DNA polymerase, $10 \mu \mathrm{M}$ each primer, $10 \mu \mathrm{L}$ template DNA, and ultrapure water up to a final volume of $30 \mu \mathrm{L}$. The following cycling conditions were employed: $95{ }^{\circ} \mathrm{C}$ for $5 \mathrm{~min}$; 35 cycles of $95{ }^{\circ} \mathrm{C}$ for 
$30 \mathrm{~s}, 52{ }^{\circ} \mathrm{C}$ for $30 \mathrm{~s}$, and $72{ }^{\circ} \mathrm{C}$ for $2 \mathrm{~min}$; and a final extension at $72{ }^{\circ} \mathrm{C}$ for $7 \mathrm{~min}$. For these molecular tests, C. fetus subsp. fetus ATCC $27374^{\mathrm{T}}$ and $C$. fetus subsp. venerealis ATCC $19438^{\mathrm{T}}$ were used as positive controls, while C. jejuni NCTC 10351 was used as the negative control.

The PCR products were subjected to electrophoresis on a $1.5 \%$ agarose gel for $2 \mathrm{~h}$ at 60 $\mathrm{V}$, after which, the gels were stained with GelRed (Biotium, Fremont, USA) or $0.5 \mu \mathrm{g} / \mathrm{mL}$ ethidium bromide (Amresco, Solon, USA). Images of the gels were captured using a transilluminator (L-Pix Chemi Photo Digitizer; Loccus Biotecnologia, Cotia, Brazil) for subsequent analysis.

\section{Results and Discussion}

The use of bulls for the present study was based on the fact that they are regarded as an ideal sampling source due to their role as disseminators of BGC and BGT in breeding stock (ALVES et al., 2011), making them good epidemiological indicators of these venereal diseases (BONDURANT, 2005). Furthermore, since there are typically fewer bulls than cows in a cattle farm, the costs of diagnostic tests are lower (LAGE; LEITE, 2000; PELLEGRIN, 2002; BONDURANT, 2005).

Culture of smegma samples on Lactopep medium in order to isolate $T$. foetus failed to detect the presence of this parasite, even for samples with a positive PCR result. This may have been caused by the low sensitivity of the isolation method, which requires three consecutive negative results before an animal can be deemed free of infection by the agent in question (PELLEGRIN; LEITE, 2003). In addition, in the present work, it was not possible to observe a 45-day period of sexual rest before sample collection for BGT diagnosis by isolation, since the animals were sampled at the slaughterhouse. This may also explain the negative results of the culture tests for isolation of the $T$. foetus. According to Pellegrin and Leite (2003), the sensitivity of isolation is low when the animals to be sampled do not undergo this sexual rest period.

The absence of growth in the cultures for T. foetus isolation is consistent with studies performed in the states of Pernambuco (PAZ JÚNIOR et al., 2010) and Distrito Federal (LEAL et al., 2012), which also failed to detect this organism using the traditional isolation technique. Based on our results, the use of culture as the single diagnostic method for BGT may compromise the quality of the epidemiological data generated and the efficiency of disease control programs.

Regarding our molecular data, of the 200 samples analyzed, $8 \%(16 / 200)$ were positive for T. foetus (Figure 1), 17.5\% (35/200) for C. fetus subsp. fetus, and 13.5\% (27/200) for C. fetus subsp. venerealis (Figure 2). Four samples tested positive for both T. foetus and C. fetus subsp. venerealis, indicating the co-existence of both disease agents in certain animals. The occurrence of mixed infections with agents of venereal diseases may affect the reproductive performance of the animals and herds concerned, requiring the use of more onerous control measures and consequently causing greater economic losses.

In previous research concerning BGT carried out in Minas Gerais, Medeiros and Figueiredo (1971) determined this disease's prevalence to be $14.4 \%$, whereas Leite et al. (1997) reported that only 5.9\% of the suspicious samples sent for culture tested positive. A number of prior studies have also used PCR to diagnose BGT, revealing a prevalence of $32 \%$ in beef cattle in Spain (MENDOZA-IBARRA et al., 2012), 5.5\% in beef cattle in Texas, USA (SZONYI et al., 2012), and 4.1\% in African cattle (MADOROBA et al., 2011). However, there have been no reports of PCR being used as a diagnostic tool in the detection of BGT in Brazilian cattle. 
Figure 1. Electrophoresis of PCR products on a 1.5\% agarose gel to detect Tritrichomonas foetus. (1) Positive control (T. foetus strain K); (2) negative control (Trichomonas vaginalis strain FMV-1); (3) T. foetus-positive field sample; (4).100-bp DNA ladder.

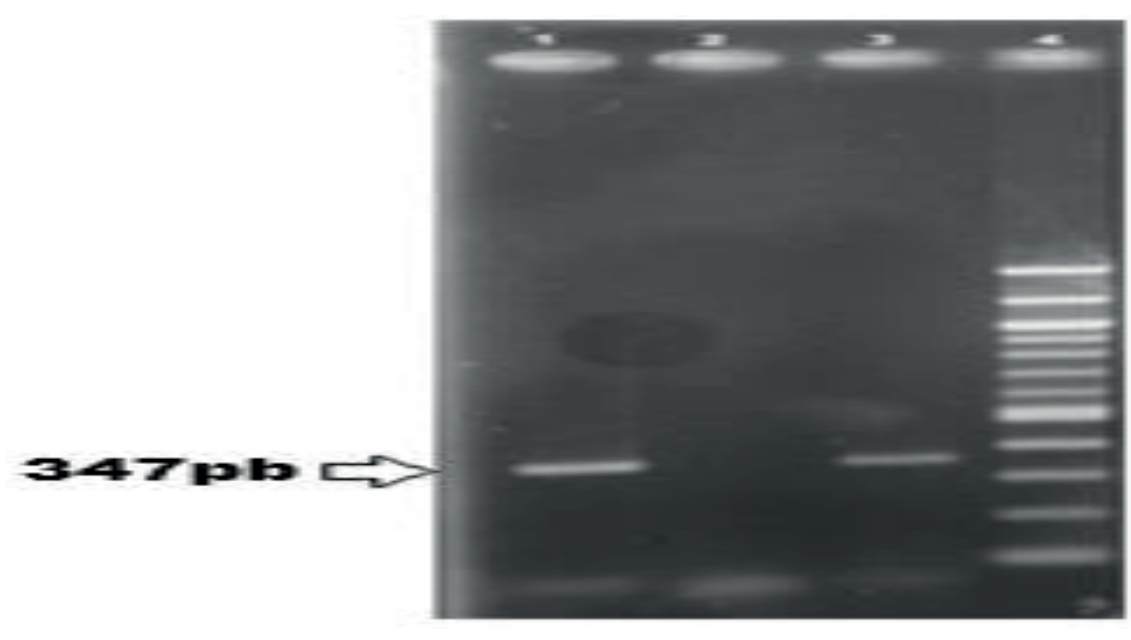

Figure 2. Electrophoresis of multiplex PCR products on a 1.5\% agarose gel for the detection of Campylobacter fetus subsp. venerealis and C. fetus subsp. fetus. (1) DNA ladder (100 bp); (2) positive controls (C. fetus subsp. fetus ATCC 273742; C. fetus subsp. venerealis ATCC 19438); (3) positive sample for C. fetus subsp. fetus; positive samples for $C$. fetus subsp. venerealis (4-7); (8) negative control (C. jejuni NCTC 103518).

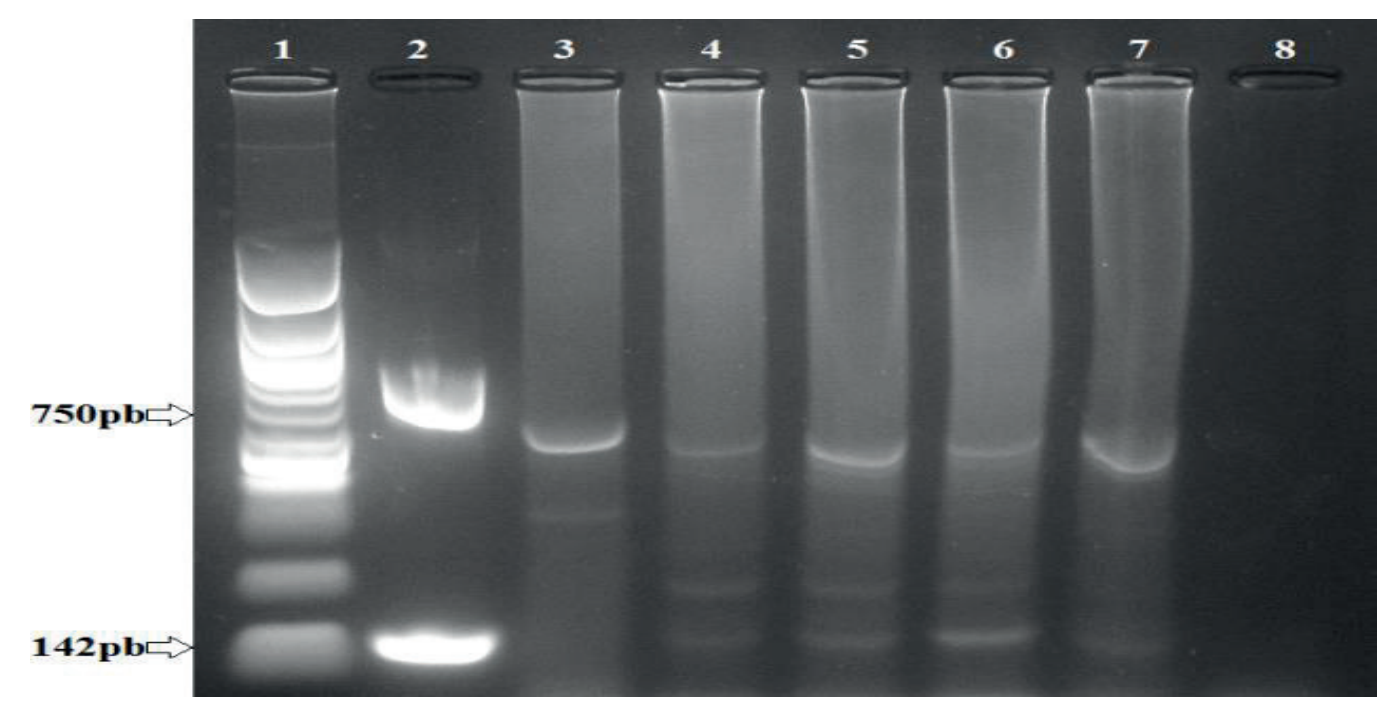

In the present work, $17.5 \%(35 / 200)$ and $13.5 \%$ (27/200) of the animals tested were positive for $C$. fetus subsp. fetus and C. fetus subsp. venerealis, respectively. Estimates of the frequency of BGC reported in previous investigations of cattle herds in Minas Gerais have been extremely variable, ranging from 0 to $46.9 \%$ (ALVES et al., 2011). In this context, it is worth mentioning the study carried out by Stynen et al. (2003) in south and southeast Minas Gerais, in which direct immunofluorescence was used to reveal that $25.5 \%$ of breeding females were positive for BGC. One of the disadvantages of this technique employing to diagnose BGC is that it does not allow for discrimination between 
C. fetus subspecies (RUCKERBAUER et al., 1974). According to our results, this can lead to an overestimation of the prevalence of this disease, considering that $17.5 \%(35 / 200)$ of samples were positive for C. fetus subsp. fetus and only $13.5 \%$ were positive for $C$. fetus subsp. venerealis.

Studies in which PCR has been used as a tool for the diagnosis of BGC remain scarce. Nevertheless, Madoroba et al. (2011) did successfully use this technique to establish the prevalence of $C$. fetus to be $1.9 \%$ among cattle in Africa. Moreover, in a study performed in Iran, Hamali et al. (2011) employed PCR to determine that $3.9 \%$ of the samples that they collected from miscarried fetuses or placentas were positive for C. fetus subsp. venerealis. In Brazil, Ziech et al. (2014) used PCR to detect C. fetus at the species level. In theory, this might also result in an overestimation of the prevalence of BGC as direct immunofluorescence, because C. fetus subsp. fetus is commonly isolated from genital secretions of bulls and cows without reproductive implications. According to Blaser et al. (2008), C. fetus subsp. fetus is the causal agent of sporadic reproductive problems in cattle mostly in association with gastrointestinal infections.

Our study revealed the occurrence of BGC and BGT in bulls sent to slaughterhouses in south Minas Gerais. Considering the infrequency with which artificial insemination is used in Brazilian cattle farming, estimated to be $11.9 \%$ by ASBIA (2014), and the fact that BGC and BGT are transmitted predominantly by natural mating (BONDURANT, 2005), our results underline the need to include these diseases in the differential diagnosis of bovine reproductive diseases and to improve and expand the infrastructure for their diagnosis among cattle herds in Brazil.

Parallels between the data concerning the prevalence of BGC (13.5\%) and BGT $(8 \%)$ in the present work and those generated in previous studies should be drawn with care, due to differences between experimental designs and diagnostic techniques that may have distinct specificities and levels of sensitivity (BONDURANT, 2005). It is worthy of note that the use of molecular techniques such as PCR, which is quick and easy and enables the analysis of large numbers of samples (HO et al., 1994), may help overcome the limitations of traditional diagnostic tests for BGC and BGT, as evidenced by the results of culture and isolation tests for T. foetus in the current study.

\section{Conclusions}

The results of the present study revealed $T$. foetus, C.fetus subsp. venerealis, and C. fetus subsp. fetus infection of bulls sent to slaughterhouses in southern Minas Gerais, indicating the occurrence of BGC and BGT among cattle in this region. For the identification of animals infected by $T$. foetus, the use of molecular tests proved more effective than detection by isolation.

\section{Acknowledgements}

We thank the Minas Gerais Research Foundation for the Master scholarship and for supporting projects developed in the Bacteriology Laboratory of the SMVP-UFLA, and the researcher José Batista de Jesus of the UFSJ for donating the Tritrichomonas foetus and Trichomonas vaginalis strains used as controls.

\section{References}

ALVES, T. M.; STYNEN, A. P. R.; MIRANDA, K. L.; LAGE, A. P. Campilobacteriose genital bovina e tricomonose genital bovina: epidemiologia, diagnóstico e controle. Pesquisa Veterinária Brasileira, Rio de Janeiro, v. 31, n. 4, p. 336-344, 2011.

ASSOCIAÇÃO BRASILEIRA DE INSEMINAÇÃO ARTIFICIAL - ASBIA. Indexx ASBIA Mercado 2014. Uberaba: ASBIA, 2014. Disponível em: <http://www. asbia.org.br/novo/upload/mercado/index 2014. pdf>. Acesso em: 22 maio 2018.

BLASER, M. J.; NEWELL, D. G.; THOMPSON, S. A.; ZECHNER, E. L. Pathogenesis of campylobacter fetus. 
In: NACHAMKIN, I.; SZYMANSKI, C. M.; BLASER, M. J. (Ed.). Campylobacter. ASM Press, Washington, DC, p. 401-428. 2008.

BONDURANT, R. H. Venereal diseases of cattle: natural history, diagnosis, and the role of vaccines in their control. The Veterinary Clinics of North America: Food Animal Practice, Philadelphia, v. 21, n. 2, p. 383-408, 2005.

CASTRO, A. F. P.; GIORGI, W.; AOKII, D.; HENRIQUES, J. Pesquisas de aglutininas anti-Vibrio fetus em mucos vaginais de rebanhos bovinos dos Estados de São Paulo, Minas Gerais e Paraná. Biológico, São Paulo, v. 37, p. 115-118, 1971.

FASSIO, L. H.; REIS, R. P.; GERALDO, L. G. Desempenho técnico e econômico da atividade leiteira em Minas Gerais. Ciência e Agrotecnologia, Lavras, v. 30, n. 6, p. 1154-1161, 2006.

FELLEISEN, R. S.; LAMBELET, N.; BACHMANN, P.; NICOLET, J.; MULLER, N.; GOTTSTEIN, B. Detection of Tritrichomonas foetus by PCR and DNA enzyme immunoassay based on rRNA gene unit sequences. Journal of Clinical Microbiology, Washington, v. 36, n. 2, p. 513-519, 1998.

HAMALI, H.; NOFOUZI, K.; JAFARI, R. A molecular (PCR) survey on abortions caused by Campylobacter spp. in the dairy cattle of Tabriz-Iran. Online Journal of Animal and Feed Research (OJAFR), Marāghah, v. 1, n. 5, p. 205-208, 2011.

HO, M. S.; CONRAD, P. A.; CONRAD, P. J.; LEFEBVRE, R. B.; PEREZ, E.; BONDURANT, R. H. Detection of bovine trichomoniasis with a specific DNA probe and PCR amplification system. Journal of Clinical Microbiology, Washington, v. 32, n. 1, p. 98-104, 1994.

HUM, S.; QUINN, K.; BRUNNER, J.; ON, S. L. Evaluation of a PCR assay for identification and differentiation of Campylobacter fetus subspecies. Australian Veterinary Journal, Victoria, v. 75, n. 11, p. 827-831, 1997.

INSTITUTO BRASILEIRO DE GEOGRAFIA E ESTATÍSTICA - IBGE. Estatística da Produção Pecuária 2017. Instituto Brasileiro de Geografia e Estatística. Rio de Janeiro, v. 1, n. 1, p. 1-78, 2017.

. Pesquisa Pecuária Municipal (PPM). Instituto Brasileiro de Geografia e Estatística, 2015. Disponível em: <https://sidra.ibge.gov.br/pesquisa/ppm/quadros/ brasil/2015>. Acesso em: 10 dez. 2015.

LAGE, A. P.; LEITE, R. C. Campilobacteriose genital bovina (Vibriose). Pecuária de Corte, São Paulo, v. 100, p. 50-54, 2000.

LEAL, D. R.; FERNANDES, G. O.; GOUVEIA, F.
F.; MIRANDA, K. L.; NEVES, J. P. Prevalência da campilobacteriose e da tricomonose genitais bovinas no Distrito Federal e em seu entorno. Revista Brasileira de Reprodução Animal, Belo Horizonte, v. 36, n. 4, p. 256259, 2012.

LEITE, R. C.; PELLEGRIN, A. O.; MARTINS, N. E.; SILVA, N.; GOMES, L. I.; COSTA, G. M.; REINATO, A. P. R.; GUIMARAES, P. H. S.; LAGE, A. P. Tricomonose bovina: diagnósticos realizados na Escola de Veterinária da UFMG no período de 1979 a 1995. Revista Brasileira de Reprodução Animal, Belo Horizonte, v. 21, n. 2, p. 166-168, 1997.

MADOROBA, E.; GELAW, A.; HLOKWE, T.; MNISI, M. Prevalence of Campylobacter fetus and Tritrichomonas foetus among cattle from Southern Africa. African Journal of Biotechnology, Nairobi, v. 10, n. 50, p. 10311-10314, 2011.

MCMILLEN, L.; FORDYCE, G.; DOOGAN, V. J.; LEW, A. E. Comparison of culture and a novel 5' Taq nuclease assay for direct detection of Campylobacter fetus subsp. venerealis in clinical specimens from cattle. Journal of Clinical Microbiology, Washigton, v. 44, n. 3, p. 938-945, 2006.

MEDEIROS, P. M.; FIGUEIREDO, J. B. Tricomonose bovina em alguns municípios do Estado de Minas Gerais. Arquivo da Escola de Veterinária de UFMG, Belo Horizonte, v. 23, p. 143-147, 1971.

MENDOZA-IBARRA, J. A.; PEDRAZA-DIAZ, S.; GARCIA-PENA, F. J.; ROJO-MONTEJO, S.; RUIZSANTA-QUITERIA, J. A.; SAN MIGUEL-IBANEZ, E.; NAVARRO-LOZANO, V.; ORTEGA-MORA, L. M.; OSORO, K.; COLLANTES-FERNANDEZ, E. High prevalence of Tritrichomonas foetus infection in Asturiana de la Montana beef cattle kept in extensive conditions in Northern Spain. Veterinary Journal, London, v. 193, n. 1, p. 146-151, 2012.

MICHI, A. N.; FAVETTO, P. H.; KASTELIC, J.; COBO, E. R. A review of sexually transmitted bovine trichomoniasis and campylobacteriosis affecting cattle reproductive health. Theriogenology, v. 85, n. 5, 781791, 2016.

PAZ JÚNIOR, C. J.; ALMEIDA, H. J. O.; JÚNIOR, H. A. F.; D'ALENCAR, A. S.; GALINDO, M. K. F.; JESUS, V. L. T.; ALVES, L. C.; FAUSTINO, M. A. G. Frequência de infecção por Tritrichomonas foetus (RIEDMULLER, 1928) em bovinos leiteiros do município de Sanharó - PE. Medicina Veterinária, Recife, v. 4, n. 1, p. 6-11, 2010.

PELLEGRIN, A. O. A Campilobacteriose e Tricomonose são doenças reemergentes? Corumbá: EMBRAPA, 2002. $24 \mathrm{p}$. 
PELLEGRIN, A. O.; LEITE, R. C. Atualização sobre Tricomonose genital bovina. Corumbá: EMBRAPA, 2003. $18 \mathrm{p}$.

ROCHA, F. S. D.; JESUS, V. L. T. D.; TORRES, H. M.; GOMES, M. J. P.; FIGUEIREDO, M. J. D.; NASCIMENTO, E. R. D.; FERREIRA, T.; AQUINO, M. H. C. D. Investigação de Campylobacter fetus e Tritrichomonas foetus na mucosa prepucial de touros da região do Médio Paraíba, RJ. Ciência Rural, Santa Maria, v. 39, n. 5, p. 1587-1590, 2009.

RUCKERBAUER, G. M.; MALKIN, K.; MITCHELL, D.; BOULANGER, P. Vibriosis: demonstration of Vibrio fetus and Vibrio bubulus organisms in preputial fluid by immunofluorescence and cultural techniques. Canadian Journal of Comparative Medicine: Revue Canadienne de Medecine Comparee, Ottawa, v. 38, n. 3, p. 321-327, 1974.

STYNEN, A. P. R.; PELlEGRIN, A. O.; FÓSCOLO, C. B.; FIGUEIREDO, J. F.; CANELLA FILHO, C.; LEITE, R. C.; LAGE, A. P. Campilobacteriose genital bovina em rebanhos leiteiros com problemas reprodutivos da microrregião de Varginha - Minas Gerais. Arquivo Brasileiro de Medicina Veterinária e Zootecnia, Belo Horizonte, v. 55, n. 6, p. 766-769, 2003.

SZONYI, B.; SRINATH, I.; SCHWARTZ, A.; CLAVIJO, A.; IVANEK, R. Spatio-temporal epidemiology of Tritrichomonas foetus infection in Texas bulls based on state-wide diagnostic laboratory data. Veterinary Parasitology, Amsterdam, v. 186, n. 3-4, p. 450-455, 2012.

WORLD ORGANISATION FOR ANIMAL HEALTH - OIE. Manual of diagnostic tests and vaccines for terrestrial animals. Paris: World Organisation for Animal Health, 2012. Available at: <http://www.oie.int $>$. Accessed at: 20 dec. 2015.

ZIECH, R. E.; MACHADO, G.; KIRINUS, J. K.; LIBARDONI, F.; KESSLER, J. D.; PÖTTER, L.; VARGAS, A. C. D. Campylobacter fetus em bovinos no estado do Rio Grande do Sul. Ciência Rural, Santa Maria, v. 44, n. 1, p. 141-146, 2014. 
